Original Article

\title{
Association between Serum Ferritin and Pre-eclampsia
}

\author{
${ }^{*}$ Paul R ${ }^{1}$, Moonajilin $\mathrm{MS}^{2}$,Sarker $\mathrm{SK}^{3}$, Paul $\mathrm{H}^{4}$, Pal $\mathrm{S}^{5}$, Pal $\mathrm{S}^{6}$, Zahan $\mathrm{RR}^{7}$, Begum $\mathrm{N}^{8}$
}

\begin{abstract}
Pre-eclampsia (PE) is a major cause of maternal and prenatal morbidity and mortality in developing countries. PE occurs in about $6 \%$ of the general women population. It complicates about 5-15\% of pregnancies over 20 weeks and is responsible for $16 \%$ of maternal mortality. Pre-delivery serum Ferritin concentration was significantly higher in patients with eclampsia than in healthy pregnant women. The serum ferritin was the best sensitive marker of the iron status parameters reflecting the preeclampsia. The aim of the study is to explore the association between serum ferritin and Preeclampsia and to do a comparison of serum ferritin to assess risk of development preeclampsia between case and control.This is a case-control study with laboratory methods. The study was carried out in Sir Salimullah Medical College and Hospital. Serum Ferritin was tested in the department of biochemistry, Bangabandhu Sheikh Mujib Medical University (BSMMU). The study was carried out from January 2008 to December 2009 and the sample size was 80. $A$ total of 80 pregnant women, comprising of $40 \mathrm{PE}$ and 40 normotensive primi or multigravida in the third trimester were enrolled in the study. The mean Systolic Blood Pressure $(S B P)$ and Diastolic Blood Pressure (DBP) were significantly higher in $P E$ group on both occasions compared to normotensive women with similar chronological age
\end{abstract}

1. *Dr Ratna Paul, Assistant Professor, Department of Gynae \& Obs, Dhaka medical college (DMC), Dhaka. Email: ratna_feni@yahoo.com

2. Dr. Mst. Sabrina Moonajilin, Lecturer, Department of Public Health and Informatics, Jahangirnagar University, Savar, Dhaka-1342

3. Dr. Sujit Kumar Sarker, Assistant Professor, Colonel Malek Medical College Hospital, Bangladesh

4. Dr. Himel Paul, Medical officer, Shahid Suhardi Medical College Hospital, Bangladesh

5. Swapna Pal, chemist

6. Dr. Swatilekha Paul, Medical officer, Shahid Suhardi Medical College Hospital, Bangladesh

7. Dr. Rezoana Refat Zahan, Junior Consultant, Mohammadpur Fertility Center, Bangladesh

8. Dr. Nasima Begum, Junior consultant, Mugdha Medical College Hospital, Bangladesh

*For corrcspondence gestational age. Out of the 40 cases $65 \%$ patients had severe proteinuria $(+++)$ and $17.5 \%$ had moderate proteinuria $(++)$ and $17.5 \%$ had mild proteinuria. The difference between case and control with respect to proteinuria was bighly significant. More than two third (67.5\%) of the cases did not have any iron deficiency anemia, while the rest (32.5\%) had mild iron deficiency anemia. In the present study, the mean serum Ferritin level of PE group was almost 10 times higher $(167.11 \pm 10.43 \mathrm{ngm} / \mathrm{ml})$ than that of controls $(17.0 \pm 3.03 \mathrm{ngm} / \mathrm{ml})$ than that of control $(431.0 \pm$ $10.93 \mathrm{gm} / \mathrm{dl}$ ). More than one-third of the cases showed serum ferritin $>210 \mathrm{ngm} / \mathrm{ml}$, compared to none of the control group. Serum Ferritin level is significantly higher in preeclamptic patients than the control group.

Keywords: preeclampsia, Ferritin

\section{INTRODUCTION}

Preeclampsia (PE) is a hypertensive complication of pregnancy associated with well-documented risk for the mother and the fetus. Despite the advancement in the field of medicine, preeclampsia/eclampsia still remains the third leading cause of maternal mortality. ${ }^{1}$ It is a major cause of maternal and prenatal morbidity and mortality in developing countries.PE occurs in about $6 \%$ of the general population. It complicates about $5-15 \%$ of pregnancies over 20 weeks and is responsible for $16 \%$ of maternal mortality and $28 \%$ of prenatal mortality. ${ }^{3}$ Though preeclampsia/eclampsia is a largely preventable condition and the incidence is decreasing in developed countries. Unfortunately, such cases still pose a great problem in developing countries like Bangladesh.

$\mathrm{PE}$ is hypertension associated with proteinuria and edema, occurring primarily in nulliparas after the week of gestation, most frequently near term. Hypertension and proteinuria are simple clinical criteria for the diagnosis of $\mathrm{PE}$. Women with PE are at increased risk of complications such as abruptio placenta, acute renal failure, cerebral hemorrhage, disseminated intravascular coagulation, pulmonary edema, circulatory collapse, and eclampsia. ${ }^{4}$

$\mathrm{PE}$ is a disease of multiple theories. Among them genetic, immunological, circulatory factors, uterovascular changes, and endothelial dysfunction are important. Despite extensive research, the mechanisms of underlying PE are 
yet to be defined. ${ }^{5}$ As pathogenesis is obscure, definite preventive and curative measures are yet not possible.

Although exact etiology of PE is still unknown, results of past studies show that abnormal placentation plays a crucial role in its pathogenesis. In cases of pregnancies complicated with PE, not all the spiral arteries of the placental bed are invaded by trophoblast. Those arteries that are invaded, the first phase of trophoblastic invasion occurs normally, but the second phase does not occur and the myometrial portions of the spiral arteries retain their reactive musculoelastic walls. ${ }^{6}$ The qualitative and quantitative restriction of normal physiological changes results in restricted placental blood flow, which becomes more critical with advancing gestation as the demand of the conceptus increases. ${ }^{7}$ In addition, acute atherosis develops in the myometrial segments of the spiral arteries. Acute atherosis may progress to vessel obliteration with corresponding areas of placental infarction. ${ }^{8}$

Several independent investigators have demonstrated through studies that vascular endothelium provides a single target organ system involved in PE. The relatively new theory of endothelial injury explains many of the clinical findings in PE. ' The ischemic placenta are the cause of generalized endothelial cell damage that gives, rise to the symptoms of hypertension, proteinuria, and sudden edema characteristic of this condition. ${ }^{10}$ It has been suggested that lipid peroxidation may play or role in the pathology of PE. ${ }^{11}$ This high level of lipid hydroperoxides believed to be present in PE are among the candidate agents capable of causing such damage to the vascular euothelium. ${ }^{12}$

Serum iron concentration was higher in patients with preeclampsia (mean of $135 \mathrm{ug} / \mathrm{dl}$ ) compared to normotensive parturient (mean of $62 \mathrm{ug} / \mathrm{dl}$ ) and chronic hypertensive parturient (mean of $72 \mathrm{ug} / \mathrm{dl}$ ). Mean iron for patients with eclampsia was $203 \mathrm{ug} / \mathrm{dl}$ and $137 \mathrm{ug} / \mathrm{dl}$ ) for patients with severe preeclampsia. A concomitant increase in serum Ferritin (mean of $59 \mathrm{ng} / \mathrm{ml}$ vs $19 \mathrm{ng} / \mathrm{ml}$ for normal) persisted longer. ${ }^{13}$

Pre-delivery serum Ferritin concentration was significantly higher in patients with eclampsia than in healthy pregnant women. ${ }^{14}$ The serum Ferritin was the best sensitive marker of the iron status parameters reflecting the preeclampsia and the result may support the role of iron as a catalyzer of oxidative stress and lipid peroxidation in the pathophysiology of preeclampsia. ${ }^{15}$

Hyperferritinemia in patients with preeclampsia appears to be attributable to the combined effects of increased Ferritin synthesis and the release of intracellular Ferritin from damaged cells. ${ }^{16}$ Considering these facts, this study was designed to clarify the role of iron parameters in the pathogenesis of PE.

\section{MATERIALS AND METHODS}

1. Research design: This is a case-control study with laboratory methods.

2. Place of study: The study was carried out in the Department of Obstetrics and Gynaecology, Sir Salimullah Medical College and Hospital.Serum Ferritin was tested in the Department of Biochemistry, BSMMU.

3. Duration of study: The study was carried out from January 2008 to December 2009

4. Study population: There were 40 cases of preeclampsia and 40 normotensive pregnant women were enrolled from Sir Salimullah Medical College and Hospital, Dhaka. The normotensive pregnant women were taken as control.

5. Sampling and selection criteria: Purposive Sampling technique.

6. Sample size: 80 samples.

7. Data Collection:

\section{Inclusion criteria for a case are}

- Primigravid or multigravid women with blood pressure $140 / 90 \mathrm{mmHg}$. This rise in blood pressure was observed at least on two occasions 6 hours apart.

- Urinary protein of $0.3 \mathrm{gm} / \mathrm{L}$ or more and

- Single gestation.

\section{Inclusion criteria for control are}

- Normotensive primigravid or multigravid women matched for age and gestation with cases.

- Normal BP recording throughout pregnancy

- Urinary protein nil

- Single gestation

Relevant clinical data were recorded in the predesigned data collection sheet.

Collection of blood sample: Maintaining all aseptic precautions, $6 \mathrm{ml}$ of venous blood was drawn from the antecubital vein of each pregnant woman in the sitting position $2 \mathrm{ml}$ of that blood was taken in EDTA tube for $\mathrm{Hb} \%$ and peripheral blood film. $4 \mathrm{ml}$ of blood was immediately transferred into a clean, dry test tube and was centrifuged with 1 hour of collection. The serum thus obtained was stored at $-70^{\prime} \mathrm{C}$ until assessed. 


\section{Laboratory methods}

- Estimation of serum Ferritin by MEIA.

- Estimation of $\mathrm{Hb} \%$ by Colorimetric method.

- Estimation of blood urea, serum creatinine, serum electrolyte, random blood sugar, serum bilirubin, SGPO, SGOT by the analyzer.

\section{Procedure:}

The AxSYM Ferritin reagents and sample is pipette in the following sequence.

Sample and AxSYM Ferritin reagent require for one test is pipette by the sampling probe into various wells of a reaction vessel (RV).

Sample is Pipetted into one well of the RV. Anti Ferritin coated microparticle, anti Ferritin alkaline phosphates conjugate, specimen diluents and TRIS buffer are pipetted into another well of a reaction vessel. The RV is immediately transferred to the processing center. Further pipetting is done in the processing center.

\section{Estimation of Urinary protein:}

About $5 \mathrm{ml}$ or midstream random urine sample was collected in a clean and dry test tube. The reagent strip was dipped into the urine for making sure that all the reagent areas have contacted the urine specimen. The excess urine was removed by running the edge of the strip against the rim of the test tube and was held in horizontal position to prevent mixing of the chemical from adjacent reagent areas and to prevent contamination of hand with urine. Then the strip was properly oriented near the appropriate color chart on the container label and read the results under good lighting. Urinary protein changes the color of the reagent strip from yellow to green.Urinary protein of 0.3 $\mathrm{gm} / \mathrm{l}$ or more were considered as positive.

\section{Data Processing \& Analysis:}

Data were processed and analyzed using computer software SPSS version 11.5

\section{RESULTS}

A total of 80 pregnant women, comprising of $40 \mathrm{PE}$ and 40 normotensive primi or multigravida in the third trimester were enrolled in the study. Both the groups were matched for their chronological age and gestational age. The blood pressure was recorded on admission and 6 hours later. No significant differences were found between cases and controls with respect to age, socioeconomic status, education, parity, gravidity, gestational age, and antenatal checkup.
The means SD) SBP (mmHg) on admission was $155.25 \pm$ 14.14 for PE and $103.25 \pm 8.29$ for the control group and after 6 hours it was $145.75 \pm 8.44$ for PE and $99.75 \pm 6.20$ for the control. The mean $( \pm \mathrm{SD}) \mathrm{DBP}(\mathrm{mmHg})$ on the admission was $109.38 \pm 12.31$ for PE and $68.00 \pm 8.23$ for the control group and after 6 hours it was $10.38 \pm 10.65$ for PE and 65.25 7.51 for control. So the mean SBP and DBP were significantly higher in PE group on both occasions compared to normotensive women with similar chronological age gestational age $(\mathrm{p}<0.001)$. Of the 40 cases $65 \%$ patients had severe proteinuria $(+++)$ and $17.5 \%$ had moderate proteinuria $(++)$ and $17.5 \%$ had mild proteinuria. Whereas, none of the control groups had any degree of proteinuria. The difference between case and control with respect to proteinuria was highly significant $(\mathrm{p}<0.001)$

Table-I : The distribution of age between cases and controls

\begin{tabular}{|l|c|c|c|}
\hline \multirow{2}{*}{ Age (yrs) } & \multicolumn{2}{|c|}{ Group } & \multirow{2}{*}{$\begin{array}{c}\text { p- } \\
\text { value }\end{array}$} \\
\cline { 2 - 3 } & $\begin{array}{c}\text { Cases } \\
(\mathrm{n}=40)\end{array}$ & $\begin{array}{c}\text { Controls } \\
(\mathrm{n}=40)\end{array}$ & \\
\hline$<20$ yrs & $5,(12.5 \%)$ & $3,(7.5 \%)$ & \\
\hline $21-30$ yrs & $32,(80.0 \%)$ & $35,(87.5 \%)$ & 0.659 \\
\hline $31-40$ yrs & $3,(7.5 \%)$ & $2,(5.0 \%)$ & \\
\hline Mean age & $25.15+4.47$ & $25.68+3.55$ & \\
\hline
\end{tabular}

Table II: Distribution of educational level of cases and controls

\begin{tabular}{|l|c|c|c|}
\hline \multirow{2}{*}{ Education } & \multicolumn{2}{|c|}{ Group } & \multirow{2}{*}{$\begin{array}{c}\text { p- } \\
\text { value }\end{array}$} \\
\cline { 2 - 3 } & Cases & Controls & \\
\hline Illiterate & $14(35.0 \%)$ & $15(37.5 \%)$ & \\
\hline Primary & $17(42.5 \%)$ & $13(32.5 \%)$ & 0.693 \\
\hline Secondary & $4(10.0 \%)$ & $8(20.0 \%)$ & \\
\hline Higher Secondary & $2(5.0 \%)$ & $1(2.5 \%)$ & \\
\hline Graduate & $3(7.5 \%)$ & $3(7.5 \%)$ & \\
\hline
\end{tabular}

More than two third (67.5\%) of the cases did not have any iron deficiency anemia, while the rest $(32.5 \%)$ had mild iron deficiency anemia. In contrast, $55 \%$ of the controls exhibited mild iron deficiency anemia. The mean hemoglobin level of cases was also revealed to be significantly higher $(11.06 \pm 1.15 \mathrm{gm} / \mathrm{dl})$ than that of controls $(8.9 \pm 1.3 \mathrm{gm} / \mathrm{dl})(\mathrm{p}<0.001)$. 
Table III: Distribution of gravidity among cases and controls

\begin{tabular}{|l|c|c|c|}
\hline \multirow{2}{*}{ *Gravidity } & \multicolumn{2}{|c|}{ Group } & \multirow{2}{*}{$\begin{array}{c}* * \\
\text { value }\end{array}$} \\
\cline { 2 - 3 } & $\begin{array}{c}\text { Cases } \\
(\mathrm{n}=40)\end{array}$ & $\begin{array}{c}\text { Controls } \\
(\mathrm{n}=40)\end{array}$ & \\
\hline Primigravida & $26(65.0 \%)$ & $28(70.0 \%)$ & 0.406 \\
\hline Multigravida & $14(350 \%)$ & $12(30.0 \%)$ & \\
\hline
\end{tabular}

Table IV: Distribution of gestational age of cases and controls:

\begin{tabular}{|l|c|c|c|}
\hline \multirow{2}{*}{$\begin{array}{l}\text { Gestational age } \\
\text { (weeks) }\end{array}$} & \multicolumn{2}{|c|}{ Group } & \multirow{2}{*}{$\begin{array}{c}* * \\
\text { value }\end{array}$} \\
\cline { 2 - 3 } & $\begin{array}{c}\text { Cases } \\
(\mathrm{n}=40)\end{array}$ & $\begin{array}{c}\text { Controls } \\
(\mathrm{n}=40)\end{array}$ & \\
\hline$<37$ & $38(95.0 \%)$ & $36(90.05)$ & 0.338 \\
\hline$\geq 37$ & $2(5.0 \%)$ & $4(10.05)$ & \\
\hline $\begin{array}{l}\text { Mean gestational } \\
\text { age }\end{array}$ & $33.95+3.02$ & $33.13+3.66$ & \\
\hline
\end{tabular}

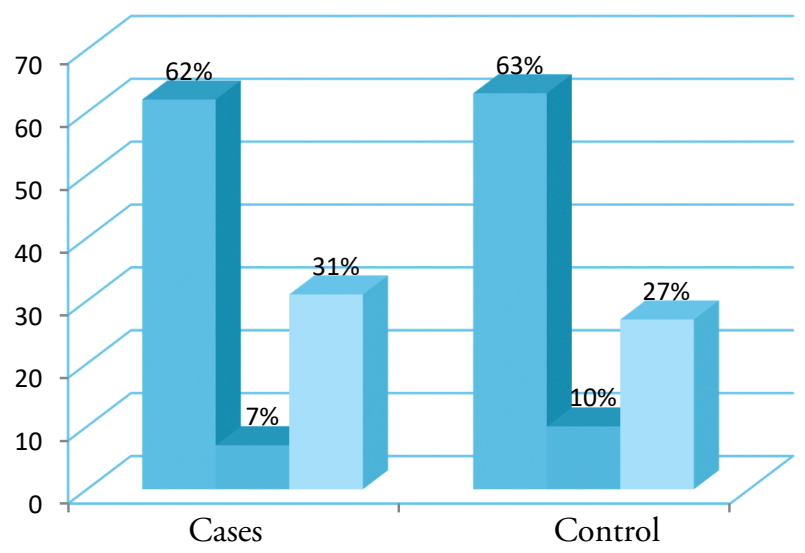

Figure-1 Distribution of Antenatal checkup

In the present study the mean serum Ferritin level of PE group was almost 10 times higher $(167.11 \pm 10.43$ $\mathrm{ngm} / \mathrm{ml})$ than that of controls $(17.0 \pm 3.03 \mathrm{ngm} / \mathrm{ml})(\mathrm{p}<85$ $\mathrm{ggm} / \mathrm{dl})$ than that of control $(431.0 \pm 10.93 \mathrm{ggm} / \mathrm{dl})$ $(\mathrm{p}<0.001)$. The systolic blood pressure of cases was observed to be significantly higher $(155.25+14.14$ $\mathrm{mmHg})$ compared to that of controls $(103.25+8.29$ $\mathrm{mmHg})(\mathrm{p}<0.001)$. The diastolic blood pressure of cases was also significantly higher $(109.38+12.31 \mathrm{mmHg})$ than that of controls $(68.0+8.23 \mathrm{mmHg})(\mathrm{p}<0.05)($ Table V).
Table V: Comparison of blood pressure on admission between case and control:

\begin{tabular}{|l|c|c|c|}
\hline \multirow{2}{*}{$\begin{array}{l}\text { Blood Pressure } \\
\text { on admission } \\
(\mathrm{mmHg})\end{array}$} & $\begin{array}{c}|c| \\
\text { Cases } \\
(\mathrm{n}=40)\end{array}$ & $\begin{array}{c}\text { Controls } \\
(\mathrm{n}=40)\end{array}$ & value \\
\hline Systolic BP & $155.25+$ & $103.25+$ & $<0.001$ \\
$($ Mean $+\mathrm{SD})$ & 14.14 & 8.29 & \\
\hline Diastolic BP & $109.38+$ & $68.0+$ & \\
(Mean + SD) & 12.31 & 8.23 & \\
\hline
\end{tabular}

In the case group, both systolic and diastolic BPS (145.75 +8.44 and $100.38+10.65 \mathrm{mmHg}$ respectively) was found to be significantly higher compared to those in the control group $(99.75+6.20$ and $65.25+7.51 \mathrm{mmHg}$ respectively $)$ 6 hours apart $(\mathrm{p}<0.001)($ Table VI).

Table VI: Comparison of blood pressure 6 hours apart between case and control( with drug):

\begin{tabular}{|l|c|c|c|}
\hline \multirow{2}{*}{$\begin{array}{l}\text { Blood Pressure } \\
\text { 6 hours apart } \\
(\mathrm{mmHg})\end{array}$} & $\begin{array}{c}|c| \\
\text { Cases } \\
(\mathrm{n}=40)\end{array}$ & $\begin{array}{c}\text { Controls } \\
(\mathrm{n}=40)\end{array}$ & value \\
\cline { 2 - 3 } & $145.75+$ & $99.75+$ & $<0.001$ \\
\hline $\begin{array}{l}\text { Systolic BP } \\
\text { (Mean + SD) }\end{array}$ & 8.44 & 6.20 & \\
\hline $\begin{array}{l}\text { Diastolic BP } \\
\text { (Mean + SD) }\end{array}$ & $\begin{array}{c}100.38+ \\
10.65\end{array}$ & $\begin{array}{c}62.25+ \\
7.51\end{array}$ & $<0.001$ \\
\hline
\end{tabular}

Table 7: Comparison of $\mathrm{Hb} \%$ between case and control

\begin{tabular}{|l|c|c|c|}
\hline \multirow{2}{*}{ Hb level } & \multicolumn{2}{|c|}{ Group } & \multirow{2}{*}{${ }^{*}$ p- } \\
\cline { 2 - 3 } & $\begin{array}{c}\text { Cases } \\
(\mathrm{n}=40)\end{array}$ & $\begin{array}{c}\text { Controls } \\
(\mathrm{n}=40)\end{array}$ & value \\
\hline $\mathrm{Hb}$ & $11.06 \pm$ & $8.9 \pm$ & $<0.001$ \\
& $1.15 \mathrm{gm} / \mathrm{dl}$ & $1.3 \mathrm{gm} / \mathrm{dl}$ & \\
\hline
\end{tabular}

Table 8 Comparison of proteinuria between case and control

\begin{tabular}{|l|c|c|c|}
\hline \multirow{2}{*}{ Proteinuria } & \multicolumn{2}{|c|}{ Group } & \multirow{2}{*}{$\begin{array}{c}* \\
\text { value }\end{array}$} \\
\cline { 2 - 3 } & $\begin{array}{c}\text { Cases } \\
(\mathrm{n}=40)\end{array}$ & $\begin{array}{c}\text { Controls } \\
(\mathrm{n}=40)\end{array}$ & \\
\hline Nil & 0 & 40 & $<0.001$ \\
\hline$(17.5 \%)$ & 7 & 0 & \\
\hline$(65.0 \%)$ & 26 & 0 & \\
\hline$(17.5 \%)$ & 7 & 0 & \\
\hline
\end{tabular}


The mean serum Ferritin level of cases was almost 10 times higher $(167.11+10.43 \mathrm{ngm} / \mathrm{ml})$ than that of controls $(17.0+3.03 \mathrm{ngm} / \mathrm{ml})(\mathrm{p}<0.001)$ (Table-IX). More than one-third of the cases showed serum Ferritin $>210 \mathrm{ngm} / \mathrm{ml}$, compared to none of the control group (Table X).

Table 9. Comparison of serum Ferritin between cases and controls:

\begin{tabular}{|c|c|c|c|}
\hline \multirow{2}{*}{$\begin{array}{l}\text { Serum iron } \\
\text { parameters }\end{array}$} & \multicolumn{2}{|c|}{ Group } & \multirow{2}{*}{$\begin{array}{c}{ }^{*} \mathrm{p}- \\
\text { value }\end{array}$} \\
\hline & $\begin{array}{l}\text { Cases } \\
(\mathrm{n}=40)\end{array}$ & $\begin{array}{c}\text { Controls } \\
(\mathrm{n}=40)\end{array}$ & \\
\hline $\begin{array}{l}\text { Serum Ferritin } \\
(\mathrm{ng} / \mathrm{ml})\end{array}$ & $\begin{array}{c}167.11+ \\
10.43\end{array}$ & $\begin{array}{c}17.0 \\
+3.03\end{array}$ & $<0.001$ \\
\hline
\end{tabular}

Table10. Comparison of serum Ferritin to assess risk of development preeclampsia between case and control:

\begin{tabular}{|l|c|c|c|}
\hline \multirow{2}{*}{ Serum Ferritin } & \multicolumn{2}{|c|}{ Group } & \multirow{2}{*}{$\begin{array}{c}\text { p- } \\
\text { value }\end{array}$} \\
\cline { 2 - 3 } & $\begin{array}{c}\text { Cases } \\
(\mathrm{n}=40)\end{array}$ & $\begin{array}{c}\text { Controls } \\
(\mathrm{n}=40)\end{array}$ & \\
\hline $\begin{array}{l}\text { Serum Ferritin } \\
(\mathrm{ng} / \mathrm{ml}) \\
(>210 \mathrm{ngm} / \mathrm{ml})\end{array}$ & $15(37.5 \%)$ & Nil & $<0.001$ \\
\hline
\end{tabular}

\section{DISCUSSION}

Studies carried out in other countries also showed similar results. Margaret el al in their study reported similar results regarding serum Ferritin in the PE patients when compared to control group.T hey showed in their study showed that percent saturation of transferrin was significantly higher in PE patients than the control group. AST level was done as an indicator of liver damage. ${ }^{17}$

Vaughan et al in their study also found that serum Ferritin was significantly higher in preeclamptic patients when compared to control group which is similar to the present study and they suggested that increased Ferritin levels may be responsible for placental oxidative stress and abnormalities in the antioxidants and thromboxane. They found no significant correlation between serum iron, serum Ferritin, total iron binding capacity, percent saturation of total iron binding capacity and indices of hepatocellular injury (AST). ${ }^{18}$
The study carried out by Vitoratos et al showed similar result regarding the mean serum Ferritin level in women with PE when compared to a matched control group

$(\mathrm{p}<0.01$ respectively). Vitoratos et al also found higher serum ceruloplasmin level compared to those control group $(\mathrm{p}<0.01)$, while the mean ferroxidase activity levels of ceruloplasmin did not differ significantly between PE group and control group. This result indicates that the plasma of preeclamptic women declines the ferroxidase activity of ceruloplasmin and reduces total iron binding capacity. Thus it seems that the plasma of preeclamptic women lacks the protective antioxidative action of this substances. ${ }^{19}$

Philip Samuel et al demonstrated a similar result regarding serum $\mathrm{Hb} \%$ in the PE patient when compared to the control group. This observation confirms the findings of Entman et a $1 .{ }^{20}$

Stephen et al reported similar results regarding mean $( \pm$ SD) serum Ferritin concentrations among preeclamptic women compared to the control group. The mean $( \pm S D)$ Ferritin level of patients with severe preeclampsia was also revealed to be significantly higher than that of patients with mild preeclampsia $(\mathrm{p}<0.02) .{ }^{21}$

In the present study percent saturation of transferrin, serum AST, LDH, ceruloplasmin, malondialdehyde, and total bilirubin were not assessed but these parameters were studied by other investigators. In the present study, the risk of developing preeclampsia was found to be associated with abnormal serum Ferritin. The study revealed that elevated serum Ferritin increases the risk of developing preeclampsia among pregnant mothers by at least two-fold.

In spite of improvement of antenatal check up, PE still remains a major health problem in the field of obstetrics both in developing countries like Bangladesh and in developed countries. It is the most important cause of maternal death in the USA, Scandinavia, Iceland, Finland and UK. ${ }^{22}$ The etiology of PE is still unknown. Several studies are going on in this field. The present study was designed to see the role of serum Ferritin in the pathophysiology of PE.

Philip Samuel et al observed the strongest correlations between serum iron, $\mathrm{LDH}$, and plasma hemoglobin. A strong correlation was also observed between total bilirubin and serum iron concentration. Parameters of 
hepatocellular damage correlated poorly with serum iron (AST, p.008). LDH can originate from red blood cells or the liver and they did not have the ability to distinguish between these isoenzymes. So they suggested that this increase in iron arise from a mild, ongoing intracellular hemolysis. $^{23}$

Hubel et al observed an increased level of serum malondialdehyde in preeclamptic patients than those of the control group. In their study electron, paramagnetic resonance spectroscopy confirmed that total transferrin in PE patients was significantly lower and percent saturation of transferrin was higher in PE than those in control group. ${ }^{24}$

\section{CONCLUSION}

Higher Serum Ferritin level are associated with preeclampsia.

\section{LIMITATION OF THE STUDY}

The researchers faced several problems during the study:

- Sample size is small

- All confounders could not be excluded

- Lack of fund and resource was a major problem of this study

- The study was confined to a tertiary care hospital and so not represented the community. So, the results might not be generalized.

\section{RECOMMENDATION}

Further studies may be conducted in larger population including other parameters like serum AST, LDH, hemopexin, total bilirubin, transferrin and percent saturation of transferrin which may affect the serum iron level in preeclampsia.

\section{REFERENCES}

1. Soule L. The Johns Hopkins Manual of Gynecology and Obstetrics, 2nd edition. Philadelphia: Lippincott Williams and Wilkins; 2002. pp 183-193.

2. Reynolds C, Mabie WC and Sibai BM. Hypertensive states of Pregnancy. In: DeCherney AH and Nathan $\mathrm{L}$ (editors), Current Obstetric and Gynecologic Diagnosis and Treatment, Edition. New York: Lange Medical Books/MCGraw-Hi11 •, 2003. pp. 338-353.

3. Shamsuddin L, Rouf $S$ and Khatun H. Perinatal Outcome of eclampsia patients.Bangladesh J ObstetGynaecol 1995; 10(2): pp 65-72.
4. Redman CWG, Roberts JM. Management of preeclampsia Lancet 1993, 341: pp 1451-1454.

5. Sumpaico WW. Management of pregnancy induced hypertension. In Ratnam S.S, Rao B and Arunlkumasan S. (editors), Obstretics and Gynaecology for Postgraduates, 2nd Edition vol I Chennai; Orient Longman Ltd; 1999; pp 56-67.

6. Greer et al, Pregnancy induced hypertension. In Chamberlein G and Steer PJ (editors) Turnbulls Obstetrics, 3rd Edition, London: Churchill Livignstone; 2001; pp 333-354.

7. Robertson WB and Khong T Y. Pathology of the uteroplacental bed. In: Sharp F and Symonds EM (editors), Hypertension in pregnancy. NY Perinatology Press:1987, pp 101.

8. Zeeman GG and Dekker GA. Pathogenesis of preeclampsia: a hypothesis. Clin Obstet Gynecol 1992; 35(2): pp 317-337.

9. Carl A Hubel A, Lisa M et al. Nonglycosylated Ferritin predominates in the circulation of women with preeclampsia but not Intrauterine growth restriction.

10. Roberts JM Taylor RN Musci TJ, Rodgers GM Hubel CA, Mc Laughlin MK Preeclampsia; an endothelial cell disorder. AM K ObstetGynecol 1989; 161: pp 1025-34.

11. Maseki M, Nishigaki I, Hagihara M, Tomoda, Y Yagi $\mathrm{K}$, Lipid peroxide levels and lipid serum content of serum lioportein fractions of pregnant subjects with and without preeclampsia. ClinChim Acta 1981; pp 155-61.

12. Warden M. Kavanagh JJ, Talavera F, Barnes D, Gaupp FB, Shulman LP, editors Precelampsia (Toxaemia of pregnancy) Medicine [serial online] 2002; Available form: URL:http://www. emedicine. $\mathrm{com} / \mathrm{med} /$ topic/905.htm.

13. Arias F. Preeclampsia and eclampsia. In: Arias F.(editor). Practical Guide to High-Risk Pregnancy an Delivery. 2nd Edition. Bangalore: Harcourt Brace and Company Asia Pvt Ltd; 1997. pp 183-210.

14. Circhton RR The biochemistry of ferritin. $\mathrm{Br} \mathrm{J}$ Haematol 1973; pp 266-77

15. Milman N, Agger AO, and Nielsen OJ. Iron status markers and serum erythropoietin in 120 mothers 
and newborn infants. Acta ObstetGynecolScand, 1994; pp 732-00.

16. Nelson-Piercy C. Hypertension in preeclampsia. In: Nelson-Piercy C. (editor) Handbook of Obstetric Medicine, 2nd Edition, London, Martin Dunitz Ltd; 2002 - pp.3-21.

17. Margaret el al: An endothelial cell disorder. Am J ObstetGynecol 1989; 161: pp 1200-1204.

18. Vaughan et al; The placental bed biopsy; review from three European Centres. Am J ObstetGynecol 1986; 155: pp 401-412.

19. Vitoratos et al ,Severe Preeclampsia, eclampsia in young primi gravis women; subsequent pregnancy outcome and remote prognosis. Am J ObstetGynecol 1986; 155: pp 1011-1016

Evans RW et al, Abnormal iron parameters in the pregnancy syndrome preeclarnpsia. Arn J Obstet Gynecol; 2002: pp 487-492.

20. Entman SS, Richardson LD and Killam PP, Altered ferrokinetics in toxemia of pregnancy: a possible indicator of decreased red cell survival. ClinExp Hypertens, 1983•, 2: pp 171.

21. Stephen et al, Maternal serum iron related parameters in severe preeclampsia. Korean J Obstet Gynecol, 2007: pp 1064

22. Balla J. Jacob HS, Balla G, Nath K, Eaton JW, Vercelotti GM. Endothelial cell heme uptake from heme proteins: induction of sensitization and desensitization to oxidant damage. Proc Natl Acad Sci USA 1993; 90: pp 9285-90

23. Philip Samuel et al Philip Samuels, Elliott K. Main Michael T. Mennuti and Steven G. Gabbe. The origin of increased serum iron in pregnancy-induced hypertension. Am J ObstetGynecol 1987; 157: pp 721-25.

24. Hubel et al Hubel CA, Roberts JM, Taylor RN, Musci TJ, Rogers GM, MC Laughlen MK Lipid peroxidation in preeclampsia: new perpectives on preeclampsia. Am J obstetGynecol 1989; 161: pp 1025-35. 